\title{
Alat Pengolah Air Tanah Menjadi Air Bersih dengan Proses Kombinasi Aerasi-Filtrasi Upflow (Desain Rancang Bangun)
}

\author{
Sri Indra Trigunarso ${ }^{1}$, Rifai Agung Mulyono ${ }^{2}$, Riyanto Suprawihadi ${ }^{3}$ \\ ${ }^{1,2}$ Jurusan Kesehatan Lingkungan, Politeknik Kesehatan Tanjungkarang, Indonesia, \\ ${ }^{3}$ Jurusan Kesehatan Lingkungan, Politeknik Kesehatan Medan, Indonesia \\ Email: trigunarsosriindra@gmail.com
}

\begin{abstract}
Groundwater Processing Equipment into Clean Water with a Combination Process of Aeration-Upflow Filtration (a Design). In areas that have not received clean water services, residents usually use well water, river water which sometimes even often the water used does not meet the standards of healthy clean water. To treat well water/ ground water is usually the community. build a processing unit in the form of a sand filter. The problem that is often encountered in treatment is cleaning the filter media. This condition is often difficult for the community to do because it requires time and energy, resulting in the sand filter that is supposed to be operational continuously and finally stops and is not even used at all. To overcome this problem, it can be done by improving the design of water treatment units with a system of combination of aeration and upflow flow filtration. This study is to determine the ability of the tool to improve the quality of shallow groundwater in terms of turbidity, Fe, Mn, color and odor to clean water and saturation point of filtering. Research Design is a "quasi-experiment" in the form of "Time Series Design" using a "pre and post test" design without control. The tool is designed in the form of an application prototype to determine its ability to reduce turbidity, Fe, Mn, color and odor and the length of saturation point. The results showed that iron content before processing 2.12 after processing 2,058. pre-treatment manganese content 0.080 after processing 0.078 . Color and smell before color processing and odor after processing are colorless and odorless. Microbiological quality for stool coly before processing week 132 after treatment 0 , week 2 coly of feces before processing 26 after processing 0 and weeks 3 coly of feces before processing 21 and after processing 0 . Length of processing up to saturation point filter media total contact time processing is 30 minutes.
\end{abstract}

Keywords: Aeration, Filtration, Shallow ground water, Upflow

\begin{abstract}
Abstrak: Alat Pengolah Air Tanah Menjadi Air Bersih Dengan Proses Kombinasi Aerasi Filtrasi Upflow (Desain Rancang Bangun). Untuk mengolah air sumur/air tanah biasanya masyarakat membangun unit pengolahan berupa saringan pasir. Masalah yang sering ditemui dalam perawatan adalah pembersihan media saring. Kondisi ini sering sulit dilakukan oleh masyarakat karena membutuhkan waktu dan tenaga sehingga mengakibatkan saringan pasir yang seharusnya beroperasional secara terus menerus akhirnya terhenti dan bahkan tidak digunakan lagi. Untuk menanggulangi masalah tersebut, dapat dilakukan dengan cara memperbaiki rancang bangun unit pengolahan air dengan sistem kombinasi aerasi dan filtrasi aliran ke atas (upflow). Tujuan penelitian mengetahui kemampuan alat dalam memperbaiki kualitas air tanah dangkal dari segi kekeruhan, Fe, Mn, warna dan bau menjadi air bersih serta titik jenuh penyaringan. Desain penelitian"eksperimen semu" berupa "Time Series Design" menggunakan rancangan "pre and post-test" tanpa kontrol. Alat dirancang berupa prototype secara aplikatif guna mengetahui kemampuannya dalam menurunkan kekeruhan, kadar Fe, Mn, warna dan bau serta lamanya titik jenuh. Hasil penelitian menunjukkan bahwa kadar zat besi besi sebelum pengolahan 2,12 setelah pengolahan 2,058. kadar mangan sebelum pengolahan 0,080 setelah pengolahan 0,078 . Warna dan bau sebelum pengolahan berwarna dan bau setelah pengolahan tidak berwarna dan tidak bau. Kualitas mikrobiologi untuk colitinja sebelum pengolahan minggu ke-1 32 setelah pengolahan 0, minggu ke-2 colitinja sebelum pengolahan 26 setelah pengolahan 0 dan minggu ke-3 colitinja sebelum pengolahan 21 dan setelah pengolahan 0 . Lamanya waktu pengolahan sampai pada titik jenuh media saring total lama kontak proses pengolahan adalah 30 menit.
\end{abstract}

Kata kunci: Aerasi, Filtrasi, Air tanah dangkal, Aliran ke atas 


\section{PENDAHULUAN}

Air merupakan kebutuhan mutlak bagi hidup dan kehidupan manusia, karena air sangat berperan dalam menjaga kelancaran sistem tubuh manusia. Komposisi air dalam tubuh manusia rata-rata $65 \%$ atau sekitar 47 liter per orang dewasa. Setiap hari sekitar 2,5 liter harus diganti dengan air yang baru. Diperkirakan dari sejumlah air yang harus diganti tersebut 1,5 liter berasal dari air minum dan sekitar 1,0 liter diperoleh dari bahan makanan yang dikonsumsi (Winarno, 1997).

Di daerah-daerah yang belum mendapatkan pelayanan air bersih, penduduk biasanya menggunakan air sumur galian, air sungai yang kadang-kadang bahkan sering kali air yang digunakan tidak memenuhi standar air bersih yang sehat. Bahkan untuk daerah yang sangat buruk kualitas air tanah maupun air sungainya, penduduk setempat hanya menggunakan air hujan untuk memenuhi kebutuhan air bersih. Sulitnya pemenuhan kebutuhan air bersih mengakibatkan masalah lain yang lebih kompleks. Salah satu masalah yang merupakan akibat dari sulitnya pemenuhan kebutuhan air bersih dan buruknya kualitas lingkungan adalah masalah kesehatan masyarakat, yaitu berjangkitnya berbagai jenis penyakit seperti muntaber, penyakit kulit dan sebagainya yang bisa dijadikan sebagai indikator buruknya kualitas lingkungan dan sulitnya pemenuhan kebutuhan air bersih.

Biasanya kualitas air sumur atau air tanah dangkal mempunyai karakteristik yang berbeda dengan kualitas air permukaan. Air tanah pada umumnya jernih, namun sering mengandung mineral-mineral atau garam-garam yang cukup tinggi, sebagai akibat dari pengaruh batuan dibawah tanah yang dilalui oleh air tanah. Pada air tanah dangkal, kualitas dan kuantitasnya dipengaruhi oleh kondisi lingkungan di permukaannya, dalam hal kuantitas sangat dipengaruhi oleh daerah asupan (recharge area) setempat, sementara kualitasnya dipengaruhi oleh kondisi sanitasi disekitarnya. Air tanah sering mengandung zat besi (Fe) dan Mangan (Mn) cukup besar. Adanya kandungan $\mathrm{Fe}$ dan $\mathrm{Mn}$ dalam air menyebabkan warna air tersebut berubah menjadi kuning-coklat setelah beberapa saat kontak dengan udara. Disamping dapat mengganggu kesehatan juga menimbulkan bau yang kurang enak serta menyebabkan warna kuning pada dinding bak serta bercak-bercak kuning pada pakaian (Widayat, 2018). Permenkes No. 492/MENKES/PER/IV/2010 menetapkan batas maksimal yang diperbolehkan dalam air minum untuk kadar $(\mathrm{Fe})$ adalah $0,3 \mathrm{mg} / \mathrm{lt}$, sedangkan kadar Mangan (Mn) yang diperbolehkan adalah 0,4 mg/lt.

Untuk mengolah air sumur dalam hal ini air tanah yang kualitasnya kurang baik menjadi air bersih yang memenuhi standar, biasanya masyarakat membangun unit pengolahan berupa saringan pasir. Saringan pasir yang sering digunakan masyarakat biasanya dengan sistem gravitasi (down flow) yaitu air dialirkan dari atas berdasarkan gaya gravitasi. Secara kualitas, penggunaan saringan pasir secara gravitasi dapat menghasilkan air olahan yang memenuhi standar kualitas air bersih, namun kendala yang sering dijumpai yang mengakibatkan saringan pasir tersebut tidak dapat operasional secara kontinyu adalah dalam hal perawatannya.

Masalah yang sering ditemui utamanya dalam hal perawatan adalah sering dijumpai bahwa setelah sekian lama saringan dioperasionalkan akan mencapai titik jenuh yang mengharuskan saringan tersebut dibersihkan. Pembersihan yang dilakukan umumnya mengangkat media pasir bagian atas untuk dilakukan pencucian yang selanjutnya dikembalikan lagi pada posisi semula. Kondisi ini sering sulit dilakukan oleh masyarakat karena membutuhkan waktu, tenaga dan hal lain yang seharusnya dapat digunakan untuk aktifitas yang lebih menghasilkan. Untuk menanggulangi masalah tersebut, dapat dilakukan dengan cara meningkatkan nilai saringan tidak hanya dari segi kemudahan operasional dan perawatan namun sekaligus menambah nilai estetikanya. Dengan demikian saringan dapat beroperasional secara kontinyu tanpa merepotkan penggunanya.

Salah satu alternatif yang dapat dilakukan adalah dengan memperbaiki rancang bangun unit pengolahan air dengan sistem kombinasi aerasi dan filtrasi aliran ke atas (upflow). Dengan arah aliran dari bawah ke atas, di mungkinkan dalam pembersihan saringan dapat dilakukan secara backwash, sehingga memudahkan dalam perawatannya. Di samping itu unit pengolah dirancang lebih menarik dan transparan agar memiliki nilai estetik yang dapat ditempatkan sebagai pelengkap asesoris di ruang tamu. Dengan adanya nilai estetika tersebut akan lebih memungkinkan pengguna akan selalu melakukan perawatan unit pengolah air tersebut. Unit Pengolahan air tersebut dapat dirancang sesuai dengan tingkat pendidikan masyarakat dan kondisi setempat. Dengan demikian alat pengolah air tanah/sumur ini harus mudah pengerjaannya serta hasil olahan yang memenuhi baku mutu air bersih. Alat tersebut terdiri dari: tangki reaktor, aerator, saringan pasir cepat, Filter mangan 
zeolit, filter karbon aktif dan sterilisator ultra violet.

\section{METODE}

Penelitian ini merupakan penelitian "eksperimen sетu" berupa "Time Series
Design" menggunakan rancangan "pre and post test" tanpa kontrol. Alat dirancang berupa prototype secara aplikatif guna mengetahui kemampuannya dalam menurunkan kekeruhan, kadar Fe, Mn, warna, bau dan mikrobiologi serta lamanya titik jenuh. Alur pikir penelitian seperti skema berikut :
SEBELUM

PERLAKUAN

Independent variable

\begin{tabular}{|l|}
\hline \multicolumn{1}{|c|}{$\begin{array}{c}\text { AIR TANAH } \\
\text { (Sumur Dangkal) }\end{array}$} \\
\hline Kandungan Besi \\
Kandungan Mangan \\
Warna \\
Bau \\
E.coli \\
\hline
\end{tabular}

Dependent variable

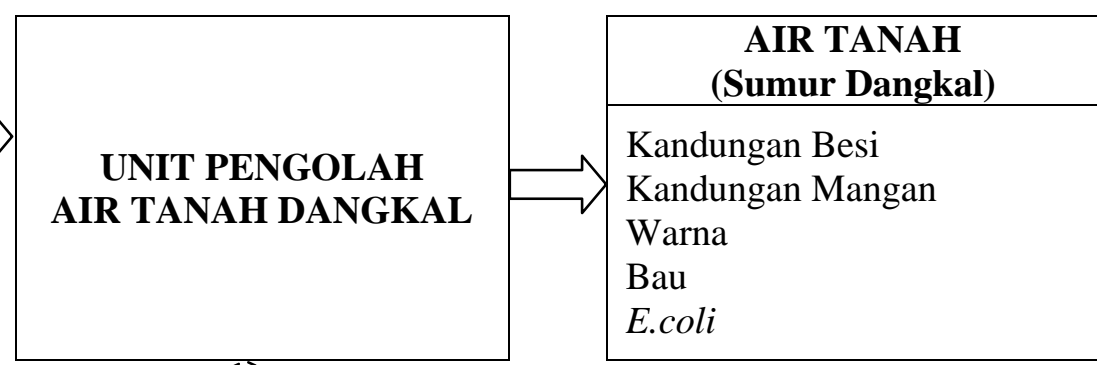

Dependent variable

\section{SESUDAH}

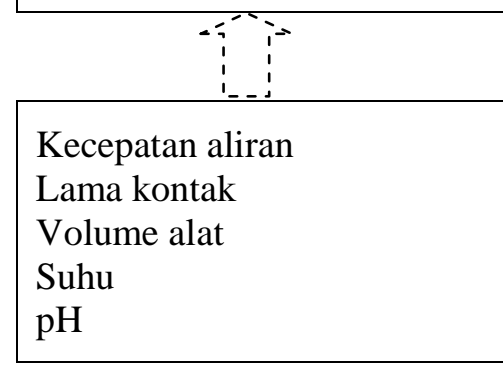

Confounding variable

HASIL

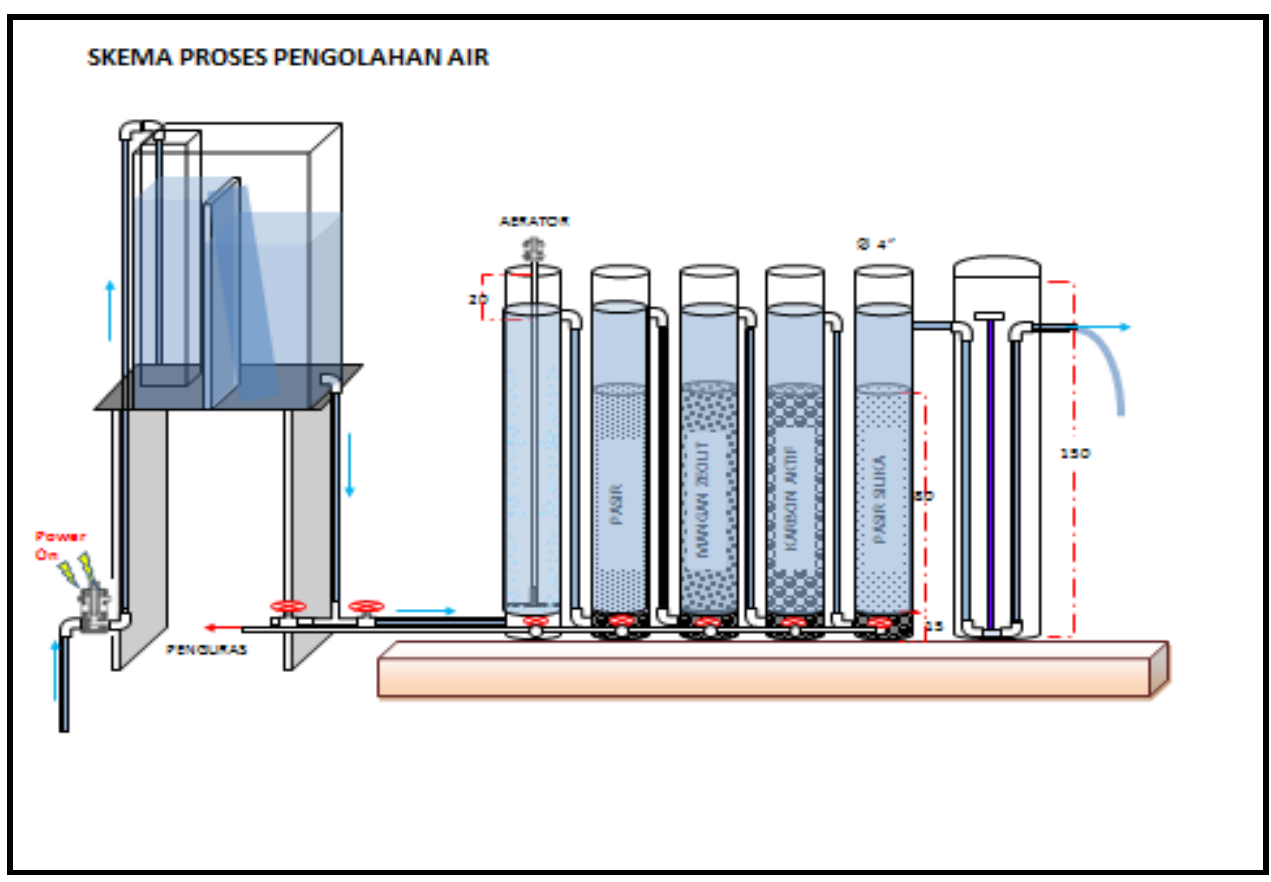

Gambar 1: Desain Rancang Bangun Alat Pengolahan Air Aerasi-Filtrasi Upflow 
Penelitian menggunakan prototype unit pengolah air tanah sebanyak 5 buah kolom (seperti gambar 1) yang masing-masing kolom memiliki volume efektif 9,5 liter ditambah satu kolom untuk disinfeksi sinar ultra violet, sehingga total volume kolom pengolahan 47,5 liter. Dalam penelitian ini kecepatan aliran. ditetapkan 1,5 liter/menit. Berdasarkan kecepatab. aliran tersebut, maka diperoleh lama kontak (HRT) untuk masing-masing kolom selama 6 menit. Sehingga total lama kontak proses pengolahan adalah 30 menit.

Pemeriksaan sampel air dilakukan sebanyak 3 kali yaitu pada minggu 1, minggu 2 dan minggu ke 3 . Hasil penelitian yang dilakukan terhadap parameter uji yang telah ditetapkan meliputi kandungan $\mathrm{Fe}$, kandungan $\mathrm{Mn}$, warna dan bau pada setiap proses adalah sebagai berikut:

\section{Kadar Zat Besi (Minggu 1 s.d Minggu 3)}

Rata-rata kadar zat besi sebelum dan sesudah pengolahan berdasarkan jenis kolom proses sebanyak 3 kali selama 3 minggu pemeriksaan adalah :

Tabel 1. Penurunan Kadar Besi dalam Air Tanah sebelum dan sesudah Pengolahan berdasarkan Kolom Proses pada minggu 1 s.d minggu 3

\begin{tabular}{|c|c|c|c|c|c|c|c|c|c|c|c|c|}
\hline \multirow{2}{*}{ KOLOM } & \multicolumn{4}{|c|}{ MINGGU 1} & \multicolumn{4}{|c|}{ MINGGU 2} & \multicolumn{4}{|c|}{ MINGGU 3} \\
\hline & Pre & Post & Selisih & $\%$ & Pre & Post & Selisih & $\%$ & Pre & Post & Selisih & $\%$ \\
\hline Awal & 2,120 & - & - & - & 2,180 & - & - & - & 2,119 & - & - & - \\
\hline Aerasi & 2,120 & 0,816 & 1,304 & 61,51 & 2,180 & 0,821 & 1,359 & 62,33 & 2,119 & 0,816 & 1,303 & 61,49 \\
\hline Koral & 0,816 & 0,360 & 0,456 & 55,88 & 0,821 & 0,380 & 0,441 & 53.71 & 0,816 & 0,358 & 0,458 & 56,12 \\
\hline Mangan zeolit & 0,360 & 0,304 & 0,056 & 15,55 & 0,380 & 0,304 & 0,076 & 20,00 & 0,358 & 0,301 & 0,057 & 15,92 \\
\hline Karbon aktif & 0,304 & 0,090 & 0,214 & 70,39 & 0,304 & 0,092 & 0,212 & 69,73 & 0,301 & 0,089 & 0,212 & 70,43 \\
\hline Pasir silika & 0,090 & 0,084 & 0,006 & 6,66 & 0,092 & 0,084 & 0,008 & 8,69 & 0,089 & 0,081 & 0,008 & 8,98 \\
\hline UV & 0,084 & 0,080 & 0,004 & 4,76 & 0,084 & 0,083 & 0,001 & 1,19 & 0,081 & 0,080 & 0,001 & 1,23 \\
\hline Penurunan & \multicolumn{4}{|c|}{2,04} & \multicolumn{4}{|c|}{2,097} & \multicolumn{4}{|c|}{2,039} \\
\hline Rata-rata & \multicolumn{12}{|c|}{2,058} \\
\hline$\%$ Penurunan & \multicolumn{4}{|c|}{96,23} & \multicolumn{4}{|c|}{96,19} & \multicolumn{4}{|c|}{96,22} \\
\hline Rata-rata \% & \multicolumn{12}{|c|}{96,19} \\
\hline
\end{tabular}

Secara series pola penurunan kadar besi dapat dilihat pada Grafik 1

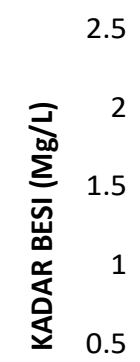

0 Zeolit Aktif Silika

KOLOM PROSES

\section{Grafik 1. Kadar Besi pada Air Tanah sebelum dan sesudah Pengolahan berdasarkan Jenis Kolom Proses}

Grafik 1 menunjukkan bahwa dari tiga kali pemeriksaan yang dilakukan selama 3 minggu ternyata terjadi penurunan kadar besi dengan pola yang sama, baik untuk minggu 1 ; minggu 2 maupun minggu 3. Hal ini menunjukkan bahwa alat pengolah tersebut masih mampu untuk menurunkan kadar besi selama penelitian berlangsung (3 minggu). 
Kadar Mangan (Minggu 1 s.d Minggu 3)

Tabel 2. Penurunan Kadar Mangan dalam Air Tanah sebelum dan sesudah Pengolahan berdasarkan Kolom Proses Minggu 1 s.d Minggu 3

\begin{tabular}{|c|c|c|c|c|c|c|c|c|c|c|c|c|}
\hline \multirow{2}{*}{ KOLOM } & \multicolumn{4}{|c|}{ MINGGU 1} & \multicolumn{4}{|c|}{ MINGGU 2} & \multicolumn{4}{|c|}{ MINGGU 3} \\
\hline & Pre & Post & Selisih & $\%$ & Pre & Post & Selisih & $\%$ & Pre & Post & Selisih & $\%$ \\
\hline Awal & 0,080 & - & - & - & 0,084 & - & - & - & 0,082 & - & - & - \\
\hline Aerasi & 0,080 & 0,033 & 0,047 & 58,75 & 0,084 & 0,046 & 0,038 & 45,23 & 0,082 & 0,041 & 0,041 & 50 \\
\hline Koral & 0,033 & 0,024 & 0,009 & 27,27 & 0,046 & 0,030 & 0,016 & 34,78 & 0,041 & 0,020 & 0,021 & 51,22 \\
\hline Mangan zeolit & 0,024 & 0,010 & 0,014 & 58,33 & 0,030 & 0,012 & 0,018 & 60 & 0,020 & 0,012 & 0,008 & 40 \\
\hline Karbon aktif & 0,010 & 0,005 & 0,004 & 40 & 0,012 & 0,006 & 0,006 & 50 & 0,012 & 0,006 & 0,006 & 50 \\
\hline Pasir silika & 0,005 & 0,004 & 0,001 & 20 & 0,006 & 0,004 & 0,002 & 33,33 & 0,006 & 0,004 & 0,002 & 33,33 \\
\hline UV & 0,004 & 0,004 & 0 & 0 & 0,004 & 0,004 & 0 & 0 & 0,004 & 0,004 & 0 & 0 \\
\hline Penurunan & & & & 0,076 & & & & 0,08 & & & & 0,078 \\
\hline Rata-rata & & & & & & & & & & & & 0,078 \\
\hline$\%$ Penurunan & & & & 95,00 & & & & 95,23 & & & & 95,12 \\
\hline$\%$ Rata-rata & & & & & & & & & & & & 95,12 \\
\hline
\end{tabular}

Tabel 2 menunjukkan bahwa dengan "Kombinasi Aerasi-Filtrasi Upflow" dapat menurunkan kadar Mangan rata-rata 0,078 $(95,12 \%)$. Tabel 2 juga menunjukkan bahwa persentase penurunan Mangan sudah terjadi sejak mulai proses aerasi hingga setelah melalui kolom filter karbon aktif. Secara series pola penurunan kadar Mangan disajikan pada Grafik 2.
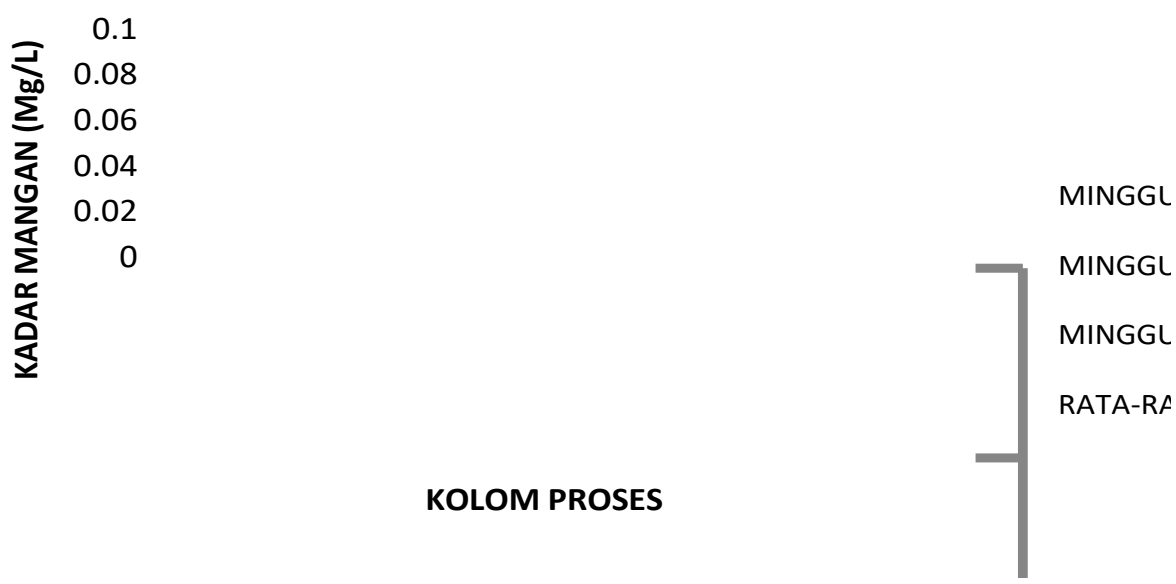

Grafik 2. Kadar Mangan pada Air Tanah sebelum dan sesudah Pengolahan berdasarkan Jenis Kolom Proses

Grafik 2 menunjukkan bahwa kadar mangan pada air tanah setelah melalui pengolahan terjadi penurunan. Dari 3 kali pemeriksaan penurunan kadar mangan pada setiap kolom proses menunjukkan pola yang sama.

\section{Warna Air dan Bau Minggu 1 s.d Minggu 3}

Air tanah dalam penelitian sebelum dilakukan proses pengolahan berwarna kuning kecoklatan dengan bau amis. Hasil pemeriksaan terhadap warna dan bau yang dilakukan secara organoleptik (pengamatan subyektif) tersaji pada Tabel 3.

Tabel 3. Penurunan Warna dan Bau pada Air Tanah sebelum dan sesudah Pengolahan berdasarkan Kolom Proses

\begin{tabular}{lccccccl}
\hline \multirow{2}{*}{ KOLOM } & \multicolumn{2}{c}{ MINGGU 1 } & \multicolumn{2}{c}{ MINGGU 2 } & \multicolumn{2}{c}{ MINGGU 3 } & \multirow{2}{*}{ Keterangan } \\
\cline { 2 - 6 } & Warna & Bau & Warna & Bau & Warna & Bau & \\
\hline Awal & ++ & ++ & ++ & ++ & ++ & ++ & Nyata warna/bau \\
Aerasi & + & + & + & + & + & + & Berwarna/bau \\
Koral & $+/$ & - & $+/-$ & - & $+/-$ & - & Berkurang warna/bau \\
Mangan zeolit & - & - & - & - & - & - & Tidak berwarna/bau \\
Karbon aktif & - & - & - & - & - & - & Tidak berwarna/bau \\
Pasir silika & - & - & - & - & - & - & Tidak berwarna/bau \\
UV & - & - & - & - & - & - & Tidak berwarna/bau \\
\hline
\end{tabular}


Tabel 3 menunjukkan bahwa adanya warna dan bau pada air tanah sebelum dilakukan pengolahan. Berkurang dan hilangnya warna dan bau air terjadi setelah melewati filter mangan zeolit.

\section{Kandungan Mikrobiologi Minggu 1 s.d Minggu 3}

Hasil penelitian kandungan mikrobiologi bakteri colitinja dan coliform sebelum dan sesudah pengolahan berdasarkan jenis kolom proses selama 3 minggu pemeriksaan adalah:

Tabel 4. Penurunan Mikrobiologi dalam Air Tanah Sebelum dan Sesudah Pengolahan berdasarkan Kolom Proses pada Minggu 1 s.d Minggu 3

\begin{tabular}{lrrrrrr}
\hline \multirow{2}{*}{ KOLOM } & \multicolumn{2}{c}{ MINGGU 1 } & \multicolumn{2}{c}{ MINGGU 2 } & \multicolumn{2}{c}{ MINGGU 3 } \\
\cline { 2 - 7 } & Colitinja & Coliform & Colitinja & Coliform & Colitinja & Coliform \\
\hline Awal & 32 & 64 & 26 & 58 & 21 & 75 \\
Aerasi & 28 & 75 & 15 & 64 & 18 & 58 \\
Koral & 21 & 44 & 15 & 42 & 15 & 48 \\
Mangan zeolit & 9 & 10 & 3 & 9 & 7 & 15 \\
Karbon aktif & 7 & 9 & 3 & 12 & 3 & 9 \\
Pasir silika & 7 & 15 & 3 & 16 & 9 & 21 \\
UV & 0 & 0 & 0 & 0 & 0 & 0 \\
\hline
\end{tabular}

Tabel 4 menunjukkan bahwa adanya kandungan mikrobiologi bakteri colitinja dan coliform pada air tanah sebelum dilakukan pengolahan. Berkurang dan hilangnya kandungan mikrobiologi bakteri colitinja dan coliform terjadi setelah melewati filter sinar UV.

\section{Hasil Pemeriksaan Kualitas Air Isi Ulang di Tiga Lokasi}

Hasil pemeriksaan kualitas air bersih air isi ulang di tiga lokasi yang dilakukan oleh petugas Laboratorium Politeknik Kesehatan Tanjungkarang adalah sebagai berikut:

Tabel 5. Kualitas Air Bersih Air Isi Ulang di Tiga Lokasi di Wilayah Provinsi Lampung

\begin{tabular}{lrrr}
\hline \multicolumn{1}{c}{ Parameter } & Lokasi 1 & Lokasi 2 & \multicolumn{1}{c}{ Lokasi 3 } \\
\hline Besi & 0,030 & 0,046 & $<0,010$ \\
Mn & 0,10 & 0,010 & 0,047 \\
Rasa & Tdk berasa & Tdk berasa & Tdk berasa \\
Bau & Tidak berbau & Tidak berbau & Tidak berbau \\
Colitinja & 0 & 0 & 0 \\
Coliform & 48 & 15 & 9 \\
\hline
\end{tabular}

Tabel 5 menunjukkan bahwa kualitas air bersih air isi ulang di tiga lokasi di wilayah provinsi lokasi 1 kadar besi 0,030, kadar Mn 0,10 , rasa dan bau tidak berasa dan berbau, colitinja 0 dan coliform 48. Lokasi 2 kadar besi 0,046, kadar Mn 0,10, rasa dan bau tidak berasa dan berbau, colitinja 0 dan coliform 15 dan untuk lokasi 3 kadar besi 0,030, kadar Mn <0,10, rasa dan bau tidak berasa dan berbau, colitinja 0 dan coliform 9.

\section{PEMBAHASAN}

Air tanah merupakan sumber utama air bersih bagi masyarakat baik diperkotaan maupun pedesaan. Meskipun air tanah merupakan sumber utama untuk air bersih, namun air tanah sering mengandung zat besi (Fe) dan Mangan (Mn) yang cukup besar. Kandungan $\mathrm{Fe}$ dan Mn dalam air dapat mengakibatkan warna air tersebut berubah menjadi kuning-coklat setelah beberapa saat kontak dengan udara. Disamping dapat mengganggu kesehatan juga menimbulkan bau yang kurang enak serta menyebabkan warna kuning pada dinding bak serta bercak-bercak kuning pada pakaian (Widayat, 2018). Oleh karena itu menurut PP No. 20 Tahun 1990 tersebut, kadar $(\mathrm{Fe})$ dalam air minum maksimum yang dibolehkan adalah $0,3 \mathrm{mg} / \mathrm{lt}$, dan kadar Mangan (Mn) dalam air minum yang dibolehkan adalah 0,1 mg/lt (Muliawan dan Ilmianih, 2016).

Untuk mendapatkan kualitas air bersih yang memenuhi standar yang berlaku, terutama sumber air yang memiliki kandungan zat besi, mangan, warna dan bau serta kandungan mikrobiologi, maka perlu dilakukan pengolahan sebelum digunakan sebagai sumber air bersih. Untuk mengolah air dengan kondisi demikian dapat digunakan alat "Kombinasi Aerasi-Filtrasi Upflow". Hasil penelitian yang telah dilakukan menunjukkan bahwa alat tersebut mampu 
menurunkan kandungan besi sampai 96,19\% dan mangan $95,12 \%$. Diketahui bahwa Kadar besi yang rendah memiliki manfaat bagi tubuh, yaitu pembentukan sel-sel darah merah, dan kandungan mangan yang berlebihan dapat menyebabkan kerusakan hati (Zahra, 2017).

Hasil penelitian juga menunjukkan warna dan bau dapat dihilangkan dengan cepat, sedangkan kandungan mikrobiologi colitinja dan coliform dapat dihilangkan setelah melewati media sinar ultra violet (UV). Sinar UV dapat secara efektif menghancurkan virus dan bakteri. Hasil ini sejalan dengan penelitian Wiyono, $\mathrm{N}$ (2017).

Persentase penurunan kandungan besi dan mangan tersebut telah mampu memenuhi standar baku mutu air bersih dengan kecepatan aliran 1,5 1/menit secara kontinyu. Penelitian ini menggunakan alat Kombinasi Aerasi-Filtrasi Upflow sebanyak 5 kolom dengan kapasitas efektif masing-masing kolom 9,5 liter, sehingga total kapasitas 47,5 liter.

Hasil penelitian menunjukkan bahwa adanya kandungan mikrobiologi bakteri colitinja dan coliform pada air tanah sebelum dilakukan pengolahan. Berkurang dan hilangnya kandungan mikrobiologi bakteri colitinja dan coliform terjadi setelah melewati filter sinar UV. Sejalan dengan penelitian Jaeman (2014) bahwa sinar UV mempunyai pengaruh yang sangat nyata terhadap kualitas mikrobiologi.

Dengan kapasitas alat 47,5 liter dan kecepatan alir 1,5 liter/menit, maka hanya membutuhkan total waktu untuk mengolah selama 31 menit. Berdasarkan spesifikasi tersebut, maka air yang dapat diolah dalam satu hari sebanyak 2.160 liter $\left(2,1 \mathrm{M}^{3}\right)$. Apabila kebutuhan air setiap orang sebesar 200 1/hari, maka air hasil pengolahan tersebut dapat memenuhi kebutuhan air bersih untuk 10 orang atau 2 keluarga.

Disisi lain apabila ditinjau dari usia alat beroperasi, dari hasil penelitian selama 3 minggu menunjukkan bahwa alat masih memiliki kemampuan untuk mengolah dengan hasil yang relatif tetap, sehingga frekuensi perawatannya relatif lebih jarang. Dengan jarangnya frekuensi perawatan, maka kebutuhan tenaga, waktu dan biaya diharapkan juga relatif sedikit.

Usia alat beroperasi dilihat relatif aman antara lain karena pada tahap awal proses (aerasi) dengan waktu 6 menit, telah mampu menurunkan kadar besi sekitar 61\%, sehingga proses selanjutnya bebannya akan lebih ringan. Ditambah dengan arah aliran dari bawah ke atas, ini memungkinkan kandungan padatan yang terjadi akan tetap berada di dasar kolom (gaya gravitasi). Demikian juga dengan kandungan Mangan yang memiliki proses relatif sama dengan proses pada zat besi. Apabila dibandingkan dengan kualitas mikrobiologi air isi ulang dari tiga lokasi terdapat perbedaan. Air isi ulang masih terdapat coliform. Sedangkan hasil penelitian setelah melewati sinar UV colitinja dan coliform sudah tidak ditemukan lagi.

Melihat kemampuan alat pengolah air tersebut dalam menurunkan kandungan zat besi, mangan, warna dan bau cukup baik serta kualitas mikrobiologi, sehingga cocok untuk diterapkan pada rumah tangga yang sumber airnya mengandung zat besi, mangan,warna dan bau cukup serta kualitas mikrobiologi. Di samping itu dengan kombinasi aerasi dan filtrasi aliran ke atas akan memudahkan dalam perawatan sekaligus meningkatkan nilai estetikanya. Karena alat tersebut dapat diletakkan di dalam rumah dan tidak mengganggu keindahan. Sedangkan untuk perawatan khususnya dalam pembersihan dapat dilakukan dengan hanya membuka kran pembilas pada bagian dasar, mengingat alat tersebut akan melakukan pencucian sendiri (backwash).

Oleh karena itu untuk rumah tangga yang mengalami kesulitan air bersih dikarenakan sumber air yang ada masih mengandung unsur tersebut di atas, penggunaan alat pengolah air ini dapat dilakukan. Dengan ukuran dan kapasitas yang ada saat ini maka dapat direkomendasikan satu alat untuk pemakaian rumah tangga. Agar dapat bermanfaat di masyarakat perlu dilakukan adanya kegiatan pengabdian masyarakat yang dilakukan oleh Politeknik Kesehatan Tanjungkarang khususnya Jurusan Kesehatan Lingkungan.

\section{SIMPULAN}

1. Kadar parameter yang diamati sebelum dan setelah pengolahan adalah: Kadar zat besi besi sebelum pengolahan 2,12 setelah pengolahan 2,058. Kadar mangan sebelum pengolahan 0,080 setelah pengolahan 0,078.

2. Warna dan bau sebelum pengolahan berwarna dan bau setelah pengolahan tidak berwarna dan tidak bau.

3. Kualitas mikrobiologi untuk colitinja sebelum pengolahan minggu ke-1 32 setelah pengolahan 0 , minggu ke-2 colitinja sebelum pengolahan 26 setelah pengolahan 0 dan minggu ke-3 colitinja sebelum pengolahan 21 dan setelah pengolahan 0 .

4. Kualitas mikrobiologi untuk coliform sebelum pengolahan minggu ke-1 64 setelah pengolahan 0 , minggu ke-2 coliform 
sebelum pengolahan 58 setelah pengolahan 0 dan minggu ke-3 coliform sebelum pengolahan 75 dan setelah pengolahan 0 .

5. Kadar parameter yang diamati pada setiap tahap pengolahan adalah :

a. Kadar zat besi setelah pengolahan ratarata 2,039 (96,22\%).

b. Kadar mangan setelah pengolahan ratarata $0,078(95,12 \%)$.

\section{DAFTAR PUSTAKA}

Departemen Kesehatan, R. I. (2010). Permenkes No. 492/Menkes/Per/IV/2010 Tentang Persyaratan Kualitas Air Minum. Jakarta: Departemen Kesehatan RI.

Jaeman, J. (2014). Pengaruh Lama Waktu Penyinaran dengan Menggunakan Sinar Ultraviolet (UV) Terhadap Kualitas Mikrobiologi Air Minum Isi Ulang. (Skripsi, IAIN Palangka Raya).

Muliawan, A., \& Ilmianih, R. (2016). Metoda Pengurangan Zat Besi Dan Mangan Menggunakan Filter Bertingkat Dengan Penambahan UV Sterilizer Skala Rumah Tangga. Jurnal Ilmiah Giga, 19(1), 1-8. c. Kadar warna dan bau setelah pengolahan tidak berwarna dan tidak bau.

d. Kualitas mikrobiologi untuk colitinja setelah tahap pengolahan 0 .

e. Kualitas mikrobiologi untuk coliform setelah tahap pengolahan 0 .

f. Lamanya waktu pengolahan sampai pada titik jenuh media saring total lama kontak proses pengolahan adalah 30 menit.

Winarno, F.G. (1997). Air untuk Industri Pangan. Jakarta: Gramedia.

Widayat, W. (2018). Teknologi Pengolahan Air Siap Minum Untuk Daerah Padat Penduduk. Jurnal Air Indonesia, 1(2).

Wiyono, N., Faturrahman, A., \& Syauqiah, I. (2017). Sistem pengolahan air minum sederhana (portable water treatment). Jurnal Konversi UNLAM, 6(1), 27-35.

Zahra, F., Fitriah, A. A., \& Basuki, F. R. (2017). Rancang Bangun Filter Air Cocoes Jaguar Untuk Mengolah Air Gambut Di Desa Sungai Tering, Kecamatan Nipah Panjang, Kabupaten Tanjung Jabung Timur, Jambi. EduFisika, 2(02), 12-17. 